\title{
Tits as bryologists: patterns of bryophyte use in nests of three species cohabiting a primeval forest
}

\author{
Tomasz Wesołowski ${ }^{1}$. Sylwia Wierzcholska ${ }^{1}$
}

Received: 25 September 2017 / Revised: 17 December 2017 / Accepted: 25 January 2018 / Published online: 12 February 2018

(C) The Author(s) 2018. This article is an open access publication

\begin{abstract}
Numerous birds use bryophytes as nest construction material but the species used and their biology remain largely unknown. Therefore, questions related to the selectivity of birds in their bryophyte use, and why they use/ignore particular species, remain unanswered. We studied the composition of bryophytes, including both mosses (Bryophyta) and liverworts (Marchantiophyta), in nests of Marsh Tit Poecile palustris, Blue Tit Cyanistes caeruleus, and Great Tit Parus major breeding sympatrically in tree cavities in pristine patches of the Białowieża National Park, Poland. We checked whether the bryophyte composition of the nests differed, compared usage of different bryophytes with their availability in the surroundings (10 $\mathrm{m}$ radius) of the tree cavities, and looked for characteristics that may have resulted in their selection as nesting material. The birds appeared to be highly selective; of 54 bryophyte species found near cavities, 21 were never used. Individual nests contained 4.0-5.5 bryophyte species on average, and only $2.3-2.7$ species exceeded 5\% of the total bryophyte volume. In each tit species the three most abundantly used bryophytes belonged to mosses and comprised ca. $80-89 \%$ of the total bryophyte volume. All of the tits utilized pleurocarpous bryophytes, growing as wefts, mats or pendants mostly on tree trunks. Simulations of plucking showed that the mosses employed as nest constituents yielded larger bundles with longer shoots when plucked. The tit species differed in the sets of bryophyte species collected. Great Tit nests contained an almost completely different assemblage of mosses from that used by Marsh and Blue Tits. This variation was related to the varying mass of their broods; more robust mosses provided support for heavier broods of Great Tits, while the finest moss species were sufficient to form a cushion for the much lighter Marsh Tit broods.
\end{abstract}

Keywords Białowieża National Park · Breeding holes · Bryophyta $\cdot$ Cyanistes caeruleus · Marchantiophyta · Parus major . Poecile palustris $\cdot$ Tree cavities

\section{Zusammenfassung}

Meisen als Moosspezialisten: Muster der Moosnutzung in Nestern von drei Arten, die gemeinsam in einem Urwald leben

Zahlreiche Vögel nutzen Moose als Nistmaterial, doch über die Identität der verwendeten Pflanzen und ihre biologischen Eigenschaften ist nicht viel bekannt. Daher bleiben Fragen, wie selektiv die Vögel bei der Auswahl der Moose sind und weshalb sie bestimmte Arten nutzen oder nicht nutzen, unbeantwortet. Wir haben die Zusammensetzung der Moospflanzen, Laubmoose (Bryophyten) sowie Lebermoose (Marchantiophyta), in den Nestern von Sumpfmeisen Poecile palustris, Blaumeisen Cyanistes caeruleus und Kohlmeisen Parus major, die sympatrisch in Baumhöhlen an unberührten

Communicated by F. Bairlein.

Electronic supplementary material The online version of this article (https://doi.org/10.1007/s10336-018-1535-2) contains supplementary material, which is available to authorized users.

Tomasz Wesołowski

tomasz.wesolowski@uwr.edu.pl

1 Laboratory of Forest Biology, Wrocław University, Sienkiewicza 21, 50335 Wrocław, Poland 
Stellen im polnischen Białowieża Nationalpark brüten, untersucht. Wir haben getestet, ob sich die Mooszusammensetzung der Nester unterschied, haben die Nutzung der verschiedenen Moospflanzen mit ihrer Verfügbarkeit in einem Radius von $10 \mathrm{~m}$ um die Nistbäume herum verglichen und nach Eigenschaften gesucht, die zu ihrer Nutzung als Nistmaterial geführt haben könnten. Die Vögel wählten die Moose offenbar höchst gezielt aus; von 54 in Höhlennähe gefundenen Moosarten wurden 21 niemals verwendet. Einzelne Nester enthielten im Durchschnitt 4,0-5,5 verschiedene Moosarten, doch lediglich 2,3-2,7 Arten übertrafen 5\% des Gesamtmoosvolumens. Bei allen untersuchten Meisenarten gehörten die drei am meisten verwendeten Moosarten zu den Laubmoosen und machten ca. 80-89\% des Gesamtmoosvolumens aus. Alle Meisenarten verwendeten pleurokarpe Moose, die in Matten oder herabhängend hauptsächlich auf Baumstämmen wuchsen. Als wir das Zupfen von Moos simulierten, zeigte sich, dass die als Nistmaterial verwendeten Moose als größere Büschel mit längeren Trieben abgezupft werden konnten. Die Meisenarten unterschieden sich hinsichtlich der Zusammenstellung der gesammelten Moosarten. Kohlmeisennester enthielten eine nahezu komplett andere Ansammlung von Moosen als die Nester von Sumpf- und Blaumeisen. Diese Variation hing mit den unterschiedlichen Brutgewichten zusammen; robustere Moose boten Unterstützung für die schwereren Kohlmeisenbruten, während die dünnsten Moosarten ausreichten, um ein Kissen für die deutlich leichteren Sumpfmeisenbruten zu bilden.

\section{Introduction}

Numerous species of small- to medium-sized birds [e.g., a quarter of species breeding in Britain (Richardson 1981)] use bryophytes as nest construction material (Hansell 2000; Glime 2017). In central Europe, mosses are also abundantly used by all of the breeding tits (Paridae), except the Willow Tit Poecile montanus (review in Glutz von Blotzheim and Bauer 1993). Mosses make up to $80 \%$ of the dry mass of Great Tit Parus major and $76 \%$ of Blue Tit Cyanistes caeruleus nests (Deeming and Mainwaring 2015). Although both mosses (Bryophyta) and liverworts (Marchantiophyta) can be utilized, they are usually not differentiated in the ornithological literature, and are collectively treated as "green mosses;" the specific identity of the plants used, or their biological properties are typically not considered. Therefore, questions of whether birds are selective in their bryophyte use, and if their decisions to use/ignore particular species are related to biological properties of the bryophytes involved, are usually not pursued.

Here, we investigate the use of bryophytes (mosses and liverworts) in nest construction by three tit species (Marsh Tit Poecile palustris, Blue and Great Tits) breeding sympatrically in the same patches of primeval forest in the Białowieża National Park (NP), eastern Poland. We document the birds' patterns of bryophyte usage, and check whether they collect bryophyte species in proportion to their availability in the environment. We also examine whether there are any interspecific differences in patterns of bryophyte use by the tits. As we expect that particular species of tits will require materials with different properties, we predict that the birds are selective and preferentially use bryophyte species with appropriate characteristics. From the conjectured functions of mosses and liverworts in the tits' nests and from the known characteristics of nests of individual tit species (Table 1) we deduce what these characteristics could
Table 1 Features of nests and broods of three tit species in the Białowieża National Park, Poland

\begin{tabular}{llcccc}
\hline Species & $\begin{array}{l}\text { Distance to } \\
\text { entrance }{ }^{\mathrm{a}}(\mathrm{cm})\end{array}$ & $\begin{array}{l}\text { Cavity area }^{\mathrm{b}} \\
\left(\mathrm{cm}^{2}\right)\end{array}$ & $\begin{array}{l}\text { Nest height } \\
(\mathrm{cm})\end{array}$ & $\begin{array}{l}\text { Nest volume }^{\mathrm{d}} \\
\left(\mathrm{cm}^{3}\right)\end{array}$ & $\begin{array}{l}\text { Brood }_{\text {mass }}^{\mathrm{e}} \\
(\mathrm{g})\end{array}$ \\
\hline Marsh Tit Poecile palustris & 14 & 80 & 9 & 720 & 90 \\
Blue Tit Cyanistes caeruleus & 15 & 115 & 5 & 575 & 130 \\
Great Tit Parus major & 20 & 230 & 11 & 2500 & 200 \\
\hline
\end{tabular}

Compiled from Wesołowski (1996, 2003), Wesołowski and Rowiński (2012, 2014), Maziarz et al. (2015, 2016) and unpublished data

${ }^{a}$ Vertical distance between lower edge of the entrance and top of nest material

${ }^{b}$ Mean area of cavity cross-section, taken at the level of the top of nest material

${ }^{c}$ Difference between mean cavity depth (vertical distance between lower edge of the entrance and the cavity bottom after the nest was removed) and the mean vertical distance from the entrance to the top of nest material

${ }^{\mathrm{d}}$ Nest area $\times$ nest height

${ }^{\mathrm{e}}$ Mass of median-sized brood (plus one parent) before fledging 
be. We then compare these predictions with the observed patterns of bryophyte use.

Strictly protected parts of the Białowieża National Park (Białowieża NP, hereafter), which preserve the last fragments of primeval temperate forest in lowland Europe, provide especially suitable conditions for this type of study. The number and diversity of tree cavities in the old-growth stands remain unaffected by human activities. Therefore cavity-nesting birds can exhibit their preferences within a full spectrum of superabundant tree cavities (see reviews in Wesołowski 2007a; Wesołowski and Martin 2018) and build nests adjusted to the conditions that exist within them (Wesołowski et al. 2002; Wesołowski and Maziarz 2012; Maziarz and Wesołowski 2014). The forest structure is highly diverse; stands are typically formed by several tree species of varying age and size. There are many snags, stumps and root pads of recently fallen trees, and fallen logs in various stages of decay (see "Study area" for details). This diversity of structures creates a plethora of opportunities for bryophytes, allowing species with diverse substrate requirements to grow in the same places (Żarnowiec et al. 1996). There are 105 bryophyte species in the oak-limehornbeam (Tilio-Carpinetum) forest habitat alone (Faliński and Mułenko 1995). One can assume that in such conditions, the usage of individual bryophyte species by the tits would be driven by their utility, and not by the lack of better alternatives.

Appropriate placement of the nest cup is crucial for the successful reproduction of birds in tree cavities (Wesołowski 2002; Wesołowski and Maziarz 2012; Maziarz and Wesołowski 2014; Maziarz et al. 2016). However, the cup containing the brood in a tit nest usually occupies only a small fraction of the cavity volume, so the birds have to find a means of fixing its position in the vertical (within the fixed distance from the cavity entrance) and horizontal (in relation to cavity walls) planes. Moreover, although the nest cups [mostly formed of soft materials of animal origin, such as fur and hair (Wesołowski 2013; Wesołowski and Rowiński 2014; Cholewa 2015)], greatly expand during the nestling period (Slagsvold 1989) they must retain their structure and position throughout the whole breeding cycle. This means that bryophytes used as filling have to provide a cushioned resilient support, robust enough to sustain movements and trampling by the growing young. This requirement is especially important in Great Tits, the heaviest species, breeding in the largest cavities [the depth of their nest cups exceeds $100 \mathrm{~cm}$ and the bottom diameter $40 \mathrm{~cm}$, in extreme cases (Maziarz et al. 2015)] and building the largest nests (Table 1). Whereas the stems of numerous bryophyte species would probably be strong enough to provide support and stability to smaller Marsh and Blue Tit nests (Table 1), we expect Great Tits to selectively use more robust species, with rigid stems and long shoots.
Tree cavities used by the tits in the Białowieża NP are generally situated inside living trees (Wesołowski 1996, 2003; Wesołowski and Rowiński 2012, 2014; Maziarz et al. 2015, 2016; unpublished data), i.e., in cool and permanently humid places (Maziarz and Wesołowski 2013; Maziarz et al. 2017). Moreover, nests in such cavities are susceptible to flooding from rainwater flowing down the trunk and by sap draining into the cavities. Despite countermeasures taken by the birds (see below) nest loss due to soaking is the second most important cause of nest failure in tree cavities in the Białowieża NP (Wesołowski et al. 2002; Wesołowski 2007a). Therefore, the requirement to keep nest contents dry is of critical importance. Large quantities of bryophytes placed inside cavities by the tits raise nest cups above the cavity bottom (Table 1), and also separate the nest cups from moist cavity walls. Bryophytes used as cavity stuffing can also serve as an efficient water absorber. Due to the lack of a thick cuticle layer, bryophytes can absorb water over their whole surface, and can also draw water directly from humid air (review in Glime 2015). Additionally, these poikilohydric plants act as sponges and, as such, remain physiologically active, and able to retain water in arrays of small chambers and capillary spaces formed especially within the mosses by their tiny leaves (review in Glime 2015). Epiphytic bryophytes, due to their high osmotic values and ability for rapid rehydration, are especially effective in this respect (Barkman 1958; review in Glime 2015). Therefore, we expect that the tits would preferentially use the most absorbent bryophytes, i.e., small-leaved epiphytic species, which form dense carpets on tree trunks.

Bryophytes do not root into a substrate, so overall they are easily detached from a surface. A broad diversity of the architecture of bryophytes results in a variety of growth forms (Meusel 1935). The stems of moss species always bear leaves, in contrast to the liverworts that are either thalloid or composed of a leafy stem. The pleurocarpous (bearing the female reproductive organs on short lateral branches) bryophytes usually adhere to their substrate and form dense wefts, mats and pendants of interwoven and protruding branching stems, while the stems of acrocarpous (the female reproductive organs are positioned terminally on the stem) bryophytes grow vertically and their single shoots form looser structures (review in Mägdefrau 1982). As it would probably be easier for the tits to pull bryophytes with their bills from a dense carpet than to collect single stems or thalli, we predict that-other things being equal—-the birds will select pleurocarpous bryophytes. In short, we expect that the tits will preferentially use mosses with a high waterabsorbing capacity, which form dense carpets of interwoven stems (wefts), to provide sufficiently strong mechanical support for their nests.

We also predict that the smaller Marsh and Blue Tits will show a similar use of mosses, whereas the larger Great Tits, which build the largest nests, will use more robust species. 


\section{Methods}

\section{Study area}

The Białowieża Forest complex is situated in the middle of the European plain, at the Polish-Belarusian border (coordinates of Białowieża village $\left.52.6833^{\circ} \mathrm{N}, 23.8667^{\circ} \mathrm{E}\right)$. The western part of the forest $\left(613 \mathrm{~km}^{2}\right.$, ca. $45 \%$ of the area) lies in Poland, and constitutes a remnant of the vast lowland forests that once covered large parts of temperate Europe. The majority of the tree stands in the Polish part are now under management, but a $47.5-\mathrm{km}^{2}$ block of the best preserved primeval old-growth stands, situated in the center of the forest, has been strictly protected within the Białowieża NP.

These primeval stands are multi-layered, with mixed species, and uneven aged. They contain many veteran trees (the tallest Norway spruce Picea abies there can reach $50 \mathrm{~m}$, and several other species reach $42-45 \mathrm{~m}$ ). The diameter at breast height of the thickest trees ranges from ca. $410 \mathrm{~cm}$ (Norway maple Acer platanoides and aspen Populus tremula) to ca. $740 \mathrm{~cm}$ (pedunculate oak Quercus robur) (Niechoda and Korbel 2011). The stands also contain large amounts of standing dead timber and fallen trees (Bobiec 2002). For more information and photographs see Tomiałojć and Wesołowski (1990, 2004); Wesołowski (2007b); and Wesołowski et al. (2010). Data on the breeding tits were gathered in four sample plots of 33-54 ha within the Białowieża NP, spaced 1-2 km apart, and covering a total area of ca. 185 ha [their distribution is shown in Wesołowski (2015)]. The study was concentrated in three plots (C, M, and $\mathrm{W}$ ) situated in oak-lime-hornbeam habitat composed mostly of hornbeam Carpinus betulus, lime Tilia cordata, pedunculate oak, spruce, and Norway maple. Data from the drier hornbeam-covered "islands," of mostly the riverine plot $(\mathrm{K})$ were also used. No nest boxes were available, and birds bred exclusively in tree cavities (Wesołowski 1996, 2001).

\section{Nest finding and retrieval}

Observations were carried out in 2015 and 2016. Intensive searches for nests were made each spring, aimed at finding all breeding cavities of Marsh Tits in all the plots (details in Wesołowski 2002, 2015). Moreover, within the plots, all cavities known to have been used for breeding by birds in previous years, situated in living trees up to $5 \mathrm{~m}$ above the ground, were checked for the presence of active tit nests. A flashlight bulb, fixed to a flexible wire, was used to light the cavity interior for inspection, with the additional use of a small mirror on a bendable handle for some cavities (Wesołowski et al. 2002). Additionally, breeding cavities were searched for during standard mapping census work (details in Wesołowski et al. 2015). The breeding cavities were checked regularly, mostly from the ground. After the chick-rearing period (fledging or failure) they were inspected closely, the lower ones from a ladder and the few higher ones by climbing, and the nests removed for examination. This was done using the method described in Hebda and Wesołowski (2012); the nests were manually removed from cavities by pulling them through the entrance by using $30-\mathrm{cm}$-long pincers or a twig with a rough surface (little hooks, knots) long enough to reach the nest through the opening. The tip was inserted deep into the nest material, then the pincers/twig were slowly turned to wind the nest material onto them. When the nest material was firmly attached to the stick, the tool with the attached nest was gently pulled through the cavity entrance. When this did not work we applied a piece of wire with an L-shaped end, or a "lasso" made of thick guitar string fixed to a stronger wire. Whichever tool was used, we first detached the nest material from the cavity walls. As the trampled nests of tits after fledging of the young are very compressed, felt-like structures, it was often possible to remove the whole nest in one piece. In the remaining cases nests were removed in fragments. The operation was considered completed when no visible remnants of nest material remained in the cavity. In a few cases the complete removal of the nest material was impossible, because of the complicated structure of the interior of the cavity. Such incompletely removed nests were excluded from the analysis. The removed nests were placed in tightly sealed, labeled plastic bags and kept in a cooler.

\section{Assessing the availability of bryophytes}

The tits frequently gathered moss in the immediate vicinity of the cavities, although they could also bring mosses from distances of up to $80 \mathrm{~m}$ (T. Wesołowski, unpublished data). However, to make sure that the mosses were actually within the birds' reach, we limited the area scrutinized to within a radius of $10 \mathrm{~m}$ of the breeding cavity. In practice such an area encompassed just the cavity tree and its nearest large neighbors. Within each radius, mosses were looked for on the ground, on fallen logs and on tree trunks up to $4 \mathrm{~m}$ above the ground (even using binoculars it was impossible to identify species with certainty at greater heights). The species were identified directly in the field, and only in (a few) cases of doubt were small reference samples collected and identified later in the lab under low-power microscopy. A species was scored as present only when it occurred in a quantity that was adequate to provide enough material to make a nest. To qualify for this, the area occupied by the species within the plot had to exceed $40 \times 40 \mathrm{~cm}$. As different species frequently grew in a fine-grained mosaic (Fig. 1), this was considered the joint area of all patches occupied by the species within a circle. The plants were identified to the species 

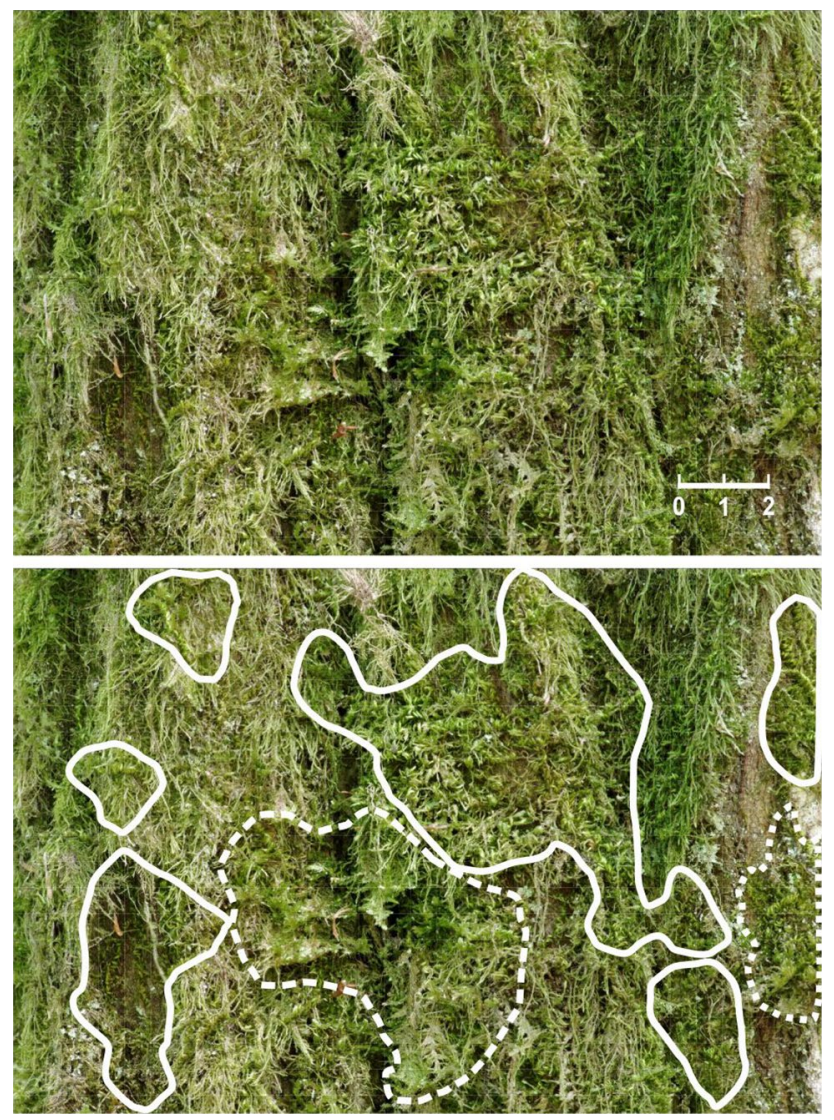

Fig. 1 Pattern of occurrence of bryophytes in the Białowieża National Park (NP), Poland. Different species are usually intermingled, and form a fine-grained patchwork. Three species, Homalothecium sericeum (surrounded by the solid line), Neckera complanata (surrounded by the dotted line) and Hypnum cupressiforme var. filiforme (the rest of the photo) growing on a ca. $12 \times 18$-cm fragment of a hornbeam trunk are visible. Color figure available online

level, except for Hypnum cupressiforme, which occurred in two morphological forms [Hypnum cupressiforme and Hypnum cupressiforme var. filiforme sensu Ando (1992); see Electronic Supplementary Material, Fig. S1]. Use of species names follows Ochyra et al. (2003) for mosses and Szweykowski (2006) for liverworts.

\section{Identification of bryophytes in nests}

Examination of bryophytes in nests took place in the lab, usually immediately (up to few days) after their collection. The nests were carefully dismantled manually, and bryophytes were separated from the rest of the nest material. The bryophyte materials were well preserved and easy to separate. All moss and liverwort fragments were then collated into species-specific groups and the share of each species of the total volume of the moss layer was assessed in $10 \%$ increments. Additionally, five percent and "plus" (when only single stems or thalli present) classes were used for the species occurring in very small quantities.

\section{Features of used vs. unused mosses}

After running preliminary analyses of moss availability and usage we learnt that some species were consistently used in nests, whilst others, although common in the forest, were hardly ever utilized. We collected samples of the seven most commonly utilized species and of the eight commonly occurring, unused ones, and measured them. This work was done in spring 2017, in the plots used for nest-finding/mossavailability assessments.

\section{Measurements of water-absorbing capacity}

To compare the water-absorbing potential of different species, we collected samples of each moss species from three different trees after 2 days of persistent heavy rain, placed them in tightly sealed plastic bags and weighed them on an electronic balance (OHAUS E11140) to the nearest $0.001 \mathrm{~g}$ immediately after bringing them to the lab. We then subtracted the standard mass of the dry bag from each measurement to arrive at the weight of water-saturated samples. Then, to obtain measures of their dry mass, the samples were repackaged into bryological envelopes, dried to a constant weight at $35^{\circ} \mathrm{C}$ for $48 \mathrm{~h}$ in a laboratory oven, then removed from the envelopes and weighed again.

\section{Assessment of ease of bryophyte plucking}

To simulate birds' collecting behavior (single pulls) we used metal tweezers with a straight, sharp triangular end $(4 \mathrm{~mm}$ wide at the base and $12 \mathrm{~mm}$ long). The size and shape mimicked those of the birds' bills, being intermediate between the actual dimensions of Marsh and Great Tit beaks (Glutz von Blotzheim and Bauer 1993). Opened tweezers (gap width ca. $5 \mathrm{~mm}$ ) were inserted into the weft at a point from which a protruding shoot was most prominent. After closing them on the shoot, the tweezers were pulled with a constant effort, perpendicular to the tree trunk. This was done by exclusively moving the wrist (the rest of the hand was immobile). To standardize the results of this artificial plucking, all pulls were done by the same person (S. W.). For each moss species we performed five pulls, each time from a different tree. The samples were individually stored, transferred to the lab, dried to a constant weight and weighed (as above). Digital optical scans of the samples were also made under standard conditions (flattened on a scanner pane, with a scale added; see Electronic Supplementary Material, Fig. S2). For each sample, the length of the longest shoot, as well as the area occupied by the moss bundle on a two-dimensional 
plane, were measured using AutoCad software (Autodesk LT 2018, version 22.0).

\section{Moss stiffness}

We used diameter of the main moss stem as a proxy for plant stiffness; this was measured only for mosses commonly used by the tits (seven species). From each sample (see above) a single shoot was removed and its stem was cut into thin slices, the diameter of which was later measured under an optical light Nikon Eclipse E600 microscope. We used a $40 \times$ eyepiece with the eyepiece micrometer (reticle) installed in it. The reticle had been calibrated using a stage micrometer, and measurements were made with $10-\mu \mathrm{m}$ resolution. For each moss species the diameters of ten randomly selected cross-sections (from ten different samples) were measured.

\section{Statistical analysis}

To analyze bryophyte species composition among tit nests we used detrended correspondence analysis, as length of the gradient (expressed as axis length) was $n>3.0 \mathrm{SD}$ units. The analysis was carried out in $\mathrm{R}$ version 3.2.2. ( $\mathrm{R}$ Core Team 2015) using the decorana() function from the vegan package (Oksanen et al. 2016). Species abundances were log transformed prior to running the analysis. The remaining statistical analyses were conducted in Statistica (StatSoft 2014, version 12). Non-parametric tests were used throughout, and all probabilities shown refer to the two-tailed tests.

\section{Results}

\section{Bryophytes in nests}

All nests $(n=81)$ were situated in the trunks of living trees, mostly in hornbeams (72\%) and limes (26\%). The number of bryophyte species found in individual nests varied between one (Great Tit) and 14 (Great Tit). The average number of bryophytes/nests ranged from 4.0 in Blue Tit to 5.5 in Marsh Tit (Table 2). Few species were used in larger (exceeding $5 \%$ ) quantities, with an average of 2.3-2.7 species/nest (Table 2), although up to six were found in Great Tit nests. The tits did not differ significantly in the number of species used (Kruskal-Wallis ANOVA, $H_{2,81}=5.32, P=0.07$ ) nor in the number of more abundant species $(H=1.57$, $P=0.46)$.

The tits used a total of 34 bryophyte species (including 30 mosses and four liverworts); 23 of them were found in Marsh Tit nests, 24 in those of Great Tits, but only 15 in Blue Tit nests (Electronic Supplementary Material, Table S1). However, each tit species regularly used (frequency $>20 \%$ ) only eight to 11 of the mosses (Table 3). Moreover, some of those frequently used species were collected only in small quantities, as an admixture, so the bulk of moss volume was composed of just three (Blue and Marsh Tits) or five (Great Tit) mosses (Table 3). In each tit species the three most abundantly used moss species comprised ca. $80-89 \%$ of the total moss volume. The tits differed in the composition of the moss species that they used most abundantly (Table 3), with smaller species (Marsh and Blue Tits) most abundantly using H. cupressiforme var. filiforme and Neckera complanata, which was scarce in Great Tit nests (Fig. 2; Kruskal-Wallis ANOVA, $H_{2,69}=10.1, P<0.007, H_{2,49}=10.1, P<0.007$, respectively). $H$. cupressiforme was used mostly by Blue and Great Tits (Fig. 2) but the difference was not significant $\left(H_{2,62}=2.6, P=0.12\right)$. Eurhynchium angustirete, Isothecium alopecuroides and Anomodon viticulosus, on the other hand, were most abundantly used by Great Tits (Fig. 2), although only in the latter moss species was the difference significant $\left(H_{2,35}=20.0, P<0.001\right)$. This was due to a significant difference in the use of this moss by Marsh and Great Tits (post hoc multiple comparison tests, $P<0.001$ ).

Overall, the combination of moss species found in Great Tit nests was so different from those found in Marsh Tit or Blue Tit nests that it was possible to identify their nests using the moss composition alone. This is confirmed by the quantitative ordination of percentage composition of different species in individual nests (Fig. 3, DCA analysis). All Great Tit nests cluster in the right-hand part of the graph (high DCA 1values) and hardly overlap with nests of the smaller species (Fig. 3). Patterns of moss use by the smaller species were more similar (they overlapped to a greater extent; Fig. 3), yet even these clearly differed in usage of some species: Metzgeria furcata was used exclusively by Marsh Tits, while Brachythecium salebrosum was found only in nests of Blue Tits (Table 3).
Table 2 Mean number and SD of bryophyte species available within $10 \mathrm{~m}$ of cavity trees used in nest construction, including those comprising $>5 \%$ of the nest volume, in three tit species in the Białowieża NP (Poland)

\begin{tabular}{|c|c|c|c|c|c|c|}
\hline \multirow[t]{2}{*}{$N$ species } & \multicolumn{2}{|c|}{ Marsh Tit $(n=44)$} & \multicolumn{2}{|c|}{ Blue Tit $(n=18)$} & \multicolumn{2}{|c|}{ Great Tit $(n=19)$} \\
\hline & Mean & SD & Mean & $\mathrm{SD}$ & Mean & SD \\
\hline Within $10-\mathrm{m}$ radius & 10.2 & 3.6 & 11.6 & 2.4 & 10.7 & 3.4 \\
\hline In nest & 5.5 & 2.3 & 4.0 & 1.8 & 5.3 & 3.4 \\
\hline$>5 \%$ of volume & 2.3 & 1.0 & 2.4 & 0.8 & 2.9 & 1.6 \\
\hline
\end{tabular}


Table 3 Usage of different bryophytes as nest construction material by three tit species in the Białowieża NP, Poland

\begin{tabular}{|c|c|c|c|c|c|c|c|c|c|}
\hline \multirow[t]{3}{*}{ Plant species } & \multicolumn{3}{|c|}{ Marsh Tit $(n=44)$} & \multicolumn{3}{|c|}{ Blue Tit $(n=18)$} & \multicolumn{3}{|c|}{ Great Tit $(n=19)$} \\
\hline & \multirow[t]{2}{*}{ Nests $(\%)$} & \multicolumn{2}{|c|}{ Vol. (\%) } & \multirow[t]{2}{*}{ Nests $(\%)$} & \multicolumn{2}{|c|}{ Vol. (\%) } & \multirow[t]{2}{*}{ Nests $(\%)$} & \multicolumn{2}{|c|}{ Vol. (\%) } \\
\hline & & Mean & SD & & Mean & SD & & Mean & SD \\
\hline Anomodon viticulosus & 39 & 1.8 & 3.0 & 11 & 0.1 & 0.0 & 84 & 53.8 & 40.5 \\
\hline Brachythecium salebrosum & 0 & 0.0 & 0.0 & 28 & 5.0 & 0.0 & 0 & 0.0 & 0.0 \\
\hline Eurhynchium angustirete & 7 & 3.4 & 5.7 & 22 & 5.1 & 9.9 & 53 & 28.0 & 32.9 \\
\hline Homalia trichomanoides & 20 & 0.1 & 0.0 & 11 & 0.1 & 0.0 & 0 & 0.0 & 0.0 \\
\hline Homalothecium sericeum & 34 & 0.8 & 1.7 & 22 & 3.8 & 4.7 & 47 & 1.7 & 2.4 \\
\hline Hypnum cupressiforme & 57 & 17.0 & 26.0 & 94 & 33.5 & 36.1 & 63 & 28.4 & 27.2 \\
\hline Hypnum cupressiforme var. filiforme & 98 & 54.2 & 37.2 & 94 & 58.5 & 39.1 & 47 & 11.1 & 18.1 \\
\hline Isothecium alopecuroides & 32 & 0.8 & 1.8 & 28 & 2.1 & 4.4 & 37 & 20.7 & 20.5 \\
\hline Leucodon sciuroides & 25 & 0.5 & 1.5 & 22 & 1.3 & 2.4 & 11 & 2.6 & 3.5 \\
\hline Metzgeria furcata (liv.) & 55 & 0.1 & 0.0 & 0 & 0.0 & 0.0 & 5 & 0.1 & 0.0 \\
\hline Neckera complanata & 84 & 41.5 & 38.6 & 33 & 26.7 & 39.7 & 32 & 0.9 & 2.0 \\
\hline Neckera pennata & 20 & 4.5 & 9.7 & 6 & 0.1 & 0.0 & 5 & 0.1 & 0.0 \\
\hline Pleurozium schreberi & 0 & 0.0 & 0.0 & 0 & 0.0 & 0.0 & 32 & 21.7 & 26.6 \\
\hline Radula complanata (liv.) & 27 & 0.1 & 0.0 & 0 & 0.0 & 0.0 & 5 & 0.1 & 0.0 \\
\hline
\end{tabular}

Percentages of nests containing individual moss species are shown, as well as the mean and SD share [\% volume (Vol. \%)] of the species in nests in which the moss was present. Bryophyte species are arranged alphabetically; unmarked species belong to the mosses. Only the species occurring at $>20 \%$ frequency (in italics) in nests of any tit species are presented. Full list of species available in the Electronic Supplementary Material, Table $\mathrm{S} 1$

liv. Liverwort

\section{Available vs. used mosses}

In total, 54 species (47 mosses, seven liverworts) were found in adequate quantities (see Methods) in at least one circular plot ( $n=81$, joint area ca. $2.5 \mathrm{ha}$ ); the full list of the species recorded is given in Electronic Supplementary Material, Table S2. They frequently occurred in intermingled patches (Fig. 1). Twenty-one species were found regularly (frequency $>20 \%$ ), and both forms of $\mathrm{H}$. cupressiforme occurred in almost all of the plots (Electronic Supplementary Material, Table S2). From four (Great Tit) to 21 (Marsh Tit) moss species were found in individual plots, and on average there were 10.2-11.6 moss species/plot (Table 2). The number of mosses found in the vicinity of cavities did not differ across the tit species (Kruskal-Wallis ANOVA, $H_{2.81}=1.02, P=0.60$ ).

Twenty-one of the available moss species were never found in the tits' nests. In most cases these were the species occurring only at low frequency, but several others were regularly available, yet they were never (e.g., Brachythecium rutabulum, Plagothecium nemorale) or hardly ever (e.g., Anomodon longifolius, Sciuro-hypnum oedipodium) used by the birds (Table 4). Mosses used frequently and in large quantities by Marsh Tits (both forms of $H$. cupressiforme and N. complanata; Table 3; Fig. 2), were also commonly found around their cavity trees (70-100\%; Electronic Supplementary Material, Table S2). The birds also brought
Metzgeria furcata frequently to the nest (Table 3) and out of proportion to its availability (Table 4), but this species always constituted only a small proportion of the nest material (Table 3). Two forms of $H$. cupressiforme used regularly and in large quantities by Blue Tits (Table 3; Fig. 2) were found in the vicinity of all of their cavity trees (Table 4). Great Tits underutilized both $H$. cupressiforme forms, but used A. viticulosus, and possibly also Pleurozium schreberi, out of proportion to their availability (Electronic Supplementary Material, Table S1).

\section{Attributes of used vs. non-used mosses}

A comparison of attributes of the used and commonly occurring but non-used species is given in the Electronic Supplementary Material (Fig. S2). The two groups did not differ in the type of substrate on which they grew; the epihytic species prevailed (five of seven used and five of eight of nonused species; Table 5). All of the tits used mostly mosses from tree trunks (Table 5, epiphytic species; Electronic Supplementary Material Fig. S1) and Great Tits additionally used the terrestrial species (Table 5; Fig. 2). However, several other species that were abundant on tree trunks were ignored (Table 5). Overall, wefts of all mosses could absorb large quantities of water, and the mass of water-saturated wefts could, in individual species, exceed their dry mass by between two and ninefold (Table 5), but the water-uptake 
Fig. 2 Interspecific differences in usage of individual moss species in nest construction by three tit species in the Białowieża NP (Poland). Shown are the median share $(\%$ volume) of the species in the moss layer, in nests, in which the moss was present. Squares indicate medians, boxes 25-75\% quartiles, and whiskers ranges; sample sizes are given in parentheses. Full names of mosses in Table 3
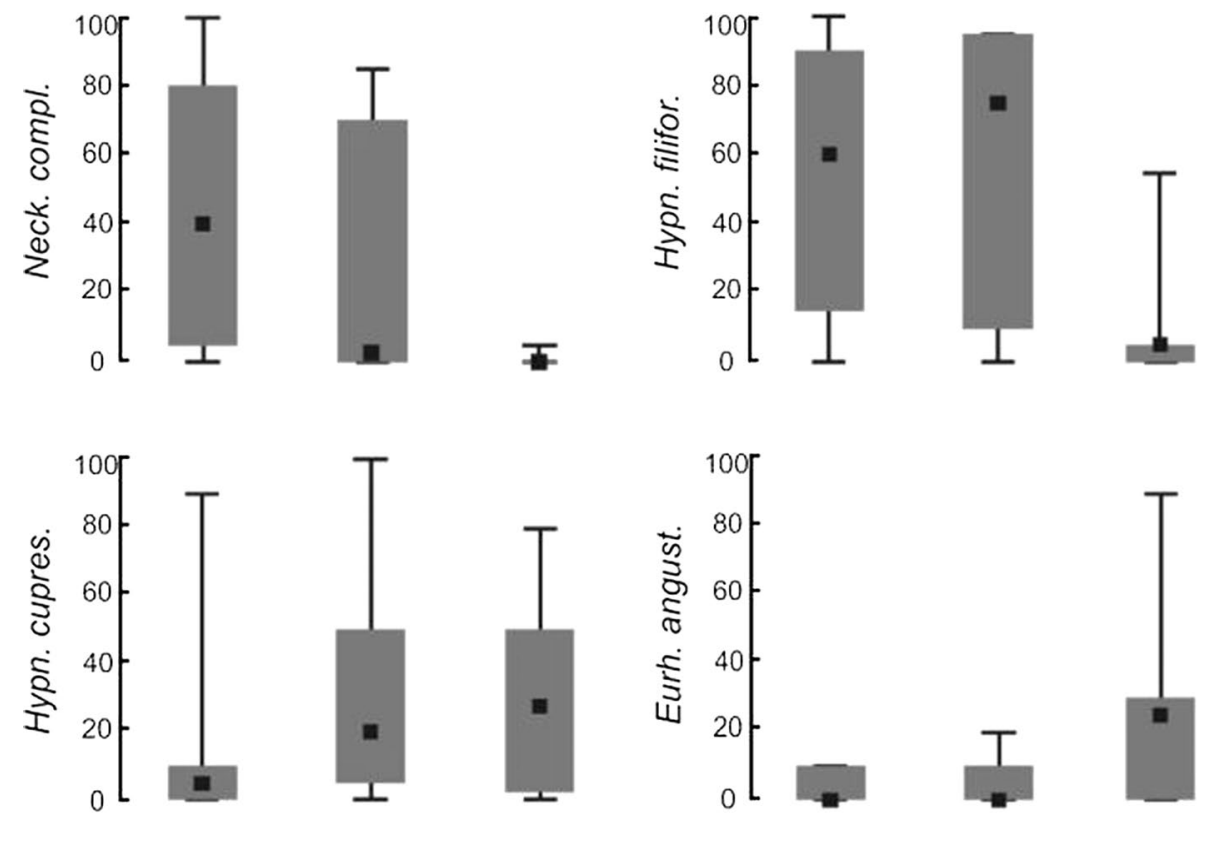

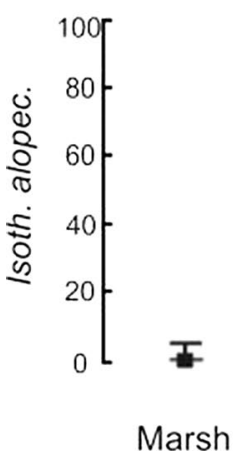

(44)
Blue (18)

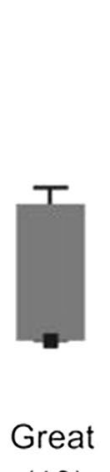

(19)

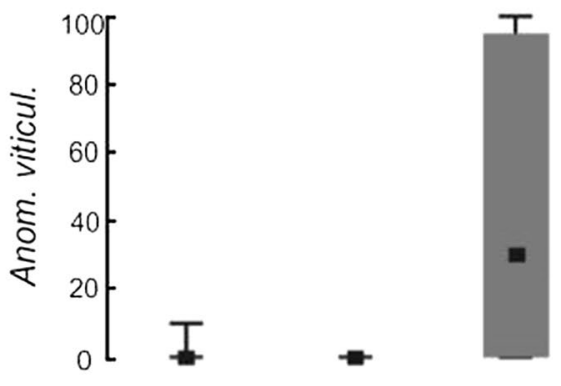

Marsh (44)

Tit species

ratio of the seven species used by tits (Table 5) did not systematically differ from those in the non-used group (eight species, mean species values; Mann-Whitney $U$-test, $Z=0.63, P=0.53$; Table 5). However, the plucked bundles of the used species were substantially larger than those of the non-used ones (Table 5). Mean shoot length of seven used species was almost twice that of the non-used ones (eight species, Mann-Whitney $U$-test, $Z=3.18, P=0.001$ ). Mean surface and mass of the used species were more than twice those of non-used species $(Z=3.07, P=0.002$ and $Z=2.37$, $P=0.02$, respectively). This was also visible within individual genera. The used $A$. viticulosus had longer shoots (Mann-Whitney $U$-test, $Z=2.51, P<0.01$ ) and tended to be plucked in larger bundles $(Z=2.09, P=0.06)$ than the nonused A. longifolius (Table 5). Similarly, the plucked bundles of the used $N$. complanata had a larger surface $(Z=2.51$, $P=0.01)$ and were heavier $(Z=1.88, P=0.06)$ than those of the non-used $N$. pennata (Table 5). The plucked bundles of moss species mainly collected by the smaller Marsh and Blue Tits (three most used species; Table 5) tended to be shorter (mean 3.2-5.4 cm) and lighter (mean 0.03-0.05 g) than those gathered by the larger Great Tits (the consecutive four species; Table 5), where the respective means ranged from 4.7 to $6.3 \mathrm{~cm}$ and $0.03-0.09 \mathrm{~g}$.

The moss species utilized by the tits differed significantly in robustness (Kruskal-Wallis ANOVA, $H_{6,70}=56.7$, $P<0.0001$; Fig. 4), with the species used mostly by Marsh Tits (H. cupressiforme var. filiforme, $N$. complanata) having a stem diameter half as thick as those used by Great Tits (Isothecium alopecuroides, Pleurozium schreberi)—Fig. 4. 


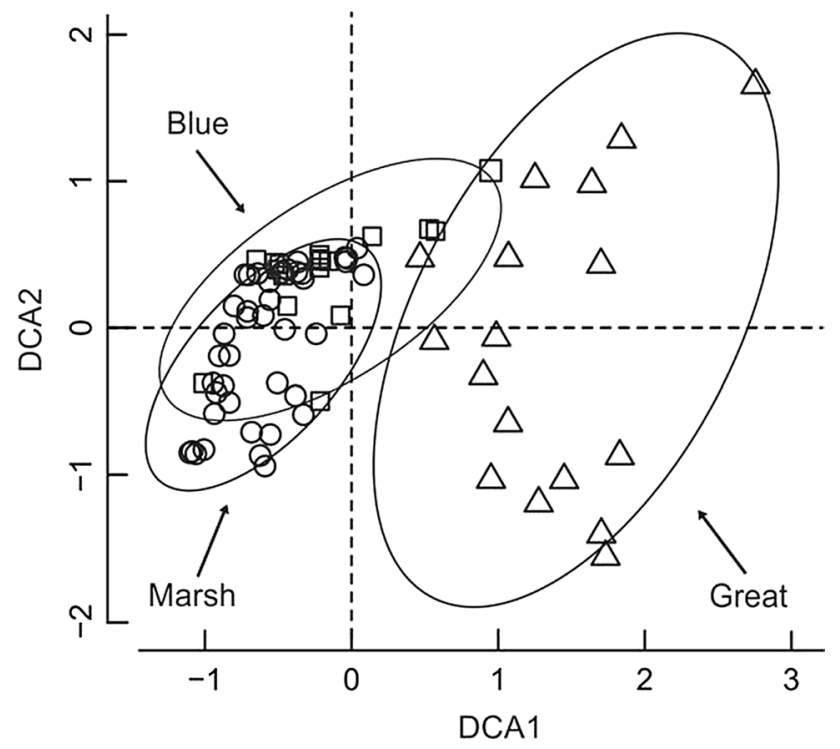

Fig. 3 Overall similarities of percentage share of moss species composition in nests of three tit species in the Białowieża NP as shown by detrended correspondence analysis (DCA). Each point represents a single nest $(n=81)$ of either Marsh Tit (circles), Blue Tit (squares) or Great Tit (triangles). DCA 1 Eigenvalue 0.63, length 3.86; DCA 2 eigenvalue 0.48 , length 3.21

\section{Discussion}

The tits in the Białowieża NP appeared to be highly selective in the mosses that they used in nest construction. Almost $40 \%$ of the more than 50 species of available mosses were never recorded in their nests, with each tit species regularly using only eight to 11 moss species, and the bulk (ca $80-89 \%$ ) of the total moss volume in their nests consisting of just three species. Other species, although present, remained underutilized. As different bryophytes were frequently intermingled, to achieve this, the birds had to be able to discriminate between species and to select the appropriate ones. A similar situation was recorded in the Japanese Tit Parus minor by Hamao et al. (2016), who found 21 moss species in nests of this species, but in $91 \%(n=47)$ of nests over $50 \%$ of the moss layer volume consisted of only three species. Such a restrictive pattern of moss use suggests that only a few moss species possess adequate functional features to be used as a nest construction material.

Some bryophytes were found in nests despite not having been recorded as available in their vicinity. This could have been due to our use of a rather conservative criterion of accessibility (species present in substantial quantities within $10 \mathrm{~m}$ of a cavity tree). The birds were not constrained by our criterion and could collect bryophytes present in smaller quantities or beyond the distance defined by us. This was probably the case with Anomodon viticulosus, the species brought to nests in abundant quantities by Great Tits. Its wefts covered mostly trunks of large Norway maples, and the closest such maples were often further than $10 \mathrm{~m}$ away. On the other hand, the disproportionately frequent presence of Metzgeria furcata in Marsh Tit nests was probably not due to its preference by the birds, but rather a by-product of this bryophyte's biology. $M$. furcata is a thallose hyperepiphyte liverwort growing on shoots of other epiphytic species (Wiśniewski 1930). Therefore, the birds plucking other bryophytes could hardly avoid gathering some shoots overgrown by Metzgeria. In line with this explanation, this liverwort was always present only as part of an admixture in nests.

Bryophytes used as a cavity nest's base have to be flexible, to allow them to be embedded into a nest structure. They also have to allow for the future expansion of the nest cup, and sufficiently robust to support the weight of the clutch, the incubating female, and then that of the growing brood. As the three tit species differed in the sizes of their selected tree cavities and mass of their broods, we predicted that Marsh Tits breeding in small cavities and having the lightest broods would use mosses with the most delicate shoots. We also expected that Great Tits would use the more robust species, with rigid stems and long shoots, while Blue Tits would use mosses intermediate to those of the other tits in this respect. This was indeed found to be the case. The two mosses with the thinnest stems, Neckera complanata, and Hypnum cupressiforme var. filiforme, which have long threadlike stems, were found mostly in Marsh Tit nests. Blue Tits used more H. cupressiforme, the shorter shoots and thicker stems of which probably provided stronger mechanical support. Great Tits hardly used the finer species utilized by Marsh Tits, but brought more robust species, with thick stems, such as Anomodon viticulosus or Pleurozium schreberi, to the nest. This pattern could not be explained as being simply a by-product of body-size differences, with larger (stronger) tit species using heavier materials. The smaller tit species were also strong enough to collect and transport the robust mosses, as demonstrated by the presence of admixtures of such mosses in their nests, but they avoided doing so. Also, the absence of delicately built mosses in Great Tit nests could certainly not be due to insufficient physical strength of this species.

Similar differences in the robustness and size of mosses used by co-occurring Blue and Great Tits was observed by Hříbek (1985) in the former Czechoslovakia (now the Czech Republic). Blue Tits used mostly softer species (H. cupressiforme, Amblystegium riparium), while Great Tits most frequently utilized two large-stemmed species (Calliergon cuspidatum, Rhytidiadelphus squarrosus).

As expected, the tits in the Białowieża NP used weftforming pleurocarpous mosses, as was observed elsewhere in Czech Blue and Great Tits by Hř́bek (1985) and in Japanese Tits by Hamao et al. (2016). Nests of Pied Flycatchers 
Table 4 Availability of different bryophytes around cavity trees and their usage in nests of three tit species in the Białowieża NP (Poland)

\begin{tabular}{|c|c|c|c|c|c|c|}
\hline \multirow[t]{2}{*}{ Plant species } & \multicolumn{2}{|c|}{ Marsh Tit $(n=44)$} & \multicolumn{2}{|c|}{ Blue Tit $(n=18)$} & \multicolumn{2}{|c|}{ Great Tit $(n=19)$} \\
\hline & Avail. $^{\mathrm{a}}(\%)$ & Usage $^{b}$ & Avail. $^{\mathrm{a}}(\%)$ & Usage $^{b}$ & Avail. $^{\text {a }}(\%)$ & Usage $^{b}$ \\
\hline Anomodon longifolius & 25 & 0.2 & 28 & 0.4 & 21 & 0.3 \\
\hline Anomodon viticulosus & 39 & 1.0 & 50 & 0.2 & 47 & 1.8 \\
\hline Brachythecium rutabulum & 23 & 0.0 & 28 & 0.0 & 11 & 0.0 \\
\hline Brachythecium salebrosum & 27 & 0.0 & 61 & 0.5 & 32 & 0.0 \\
\hline Eurhynchium angustirete & 66 & 0.1 & 83 & 0.3 & 47 & 1.1 \\
\hline Homalia trichomanoides & 75 & 0.3 & 83 & 0.1 & 89 & 0.0 \\
\hline Homalothecium sericeum & 30 & 1.2 & 44 & 0.5 & 47 & 1.0 \\
\hline Hypnum cupressiforme & 100 & 0.6 & 100 & 0.9 & 100 & 0.6 \\
\hline Hypnum cupressiforme var. filiforme & 100 & 1.0 & 100 & 0.9 & 95 & 0.5 \\
\hline Isothecium alopecuroides & 43 & 0.7 & 61 & 0.5 & 84 & 0.4 \\
\hline Leucodon sciuroides & 5 & 5.5 & 22 & 1.0 & 16 & 0.7 \\
\hline Metzgeria furcata (liv.) & 11 & 4.8 & 17 & 0.0 & 16 & 0.3 \\
\hline Neckera complanata & 70 & 1.2 & 78 & 0.4 & 79 & 0.4 \\
\hline Neckera pennata & 36 & 0.6 & 44 & 0.1 & 47 & 0.1 \\
\hline Oxyrrhynchium hians & 2 & 0.0 & 22 & 0.0 & 21 & 0.0 \\
\hline Plagiomnium cuspidatum & 36 & 0.0 & 61 & 0.0 & 32 & 0.3 \\
\hline Plagiothecium nemorale & 32 & 0.0 & 33 & 0.0 & 16 & 0.0 \\
\hline Platygyrium repens & 34 & 0.5 & 50 & 0.1 & 32 & 0.2 \\
\hline Pleurozium schreberi & 16 & 0.0 & 6 & 0.0 & 11 & 3.0 \\
\hline Radula complanata (liv.) & 20 & 1.3 & 11 & 0.0 & 16 & 0.3 \\
\hline Rhizomnium punctatum & 25 & 0.0 & 6 & 0.0 & 21 & 0.0 \\
\hline Sciuro-hypпит oedipodium & 52 & 0.1 & 33 & 0.2 & 74 & 0.2 \\
\hline
\end{tabular}

Bryophyte species are arranged alphabetically. Unmarked species are mosses, and only the species occurring at $>20 \%$ frequency in the plots or in nests (italics, cf. Table 3) of any tit species are presented. Full list of species found in nests and around them are presented in Electronic Supplementary Material, Table S1 and Table S2, respectively. Usage values significantly different (at $P<0.05$, Fisher exact probability test two-tailed) from equal are in italic

Avail. Availability

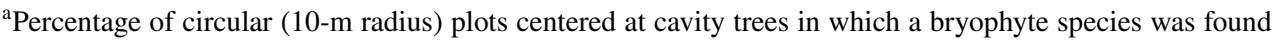
in an adequate quantity (joint area of all its patches exceeded $40 \times 40 \mathrm{~cm}$ )

${ }^{b}$ Ratio of the number of nests containing the bryophyte species relative to the number of plots with the species present
Ficedula hypoleuca in England (Briggs and Deeming 2016) and of 11 North American (non-tit) species studied by Breil and Moyle (1976) also contained mostly pleurocarpous mosses.

The tits in the Białowieża NP collected mostly bryophytes from tree trunks (epiphytic species), with only Great Tits additionally using the terrestrial species. Japanese Tits, and Czech Blue and Great Tits, on the other hand, mostly used the terrestrial species (Hř́bek 1985; Hamao et al. 2016), but it is unknown whether epiphytic bryophytes were available in their study areas. Why should trunk-growing bryophytes be preferred? This could be related to several factors, such as predator avoidance (going to the ground being more risky), minimizing costs of transport (material collected next to the cavity) or the efficiency of plucking. The results of our plucking simulations clearly indicate that the efficiency of collection could be an important factor in the choice of mosses by the birds. Although the simulations mimicked reality only roughly, they nevertheless clearly showed that plucking of the species used by the birds yielded larger (heavier) bundles of moss, and contained longer shoots, than of those mosses that were ignored by the birds. As patches of preferred and ignored species often grew side by side on the same tree trunks, the contrast in their usage was probably due to differences in the ease of collection and not to other factors.

As bryophytes fulfill a crucial water-absorbing function in tree-cavity nests (Wesołowski et al. 2002; Wesołowski 2007a), we expected that the tits would preferentially use mosses with the highest water-uptake capacity. This was not the case, though, as the water-uptake ratios did not systematically differ between the used and non-used species. Apparently, the water-absorbing capacity of the used species 
Table 5 Attributes of moss species used and not used in nest construction by tits in the Białowieża NP (Poland)

\begin{tabular}{|c|c|c|c|c|c|}
\hline Moss species & Substrate & Water-uptake ratio $^{\mathrm{a}}$ & Length $^{\mathrm{b}}(\mathrm{cm})$ & $\operatorname{Area}^{c}\left(\mathrm{~cm}^{2}\right)$ & $\operatorname{Mass}^{\mathrm{d}}(\mathrm{g})$ \\
\hline \multicolumn{6}{|l|}{ Used } \\
\hline Neckera complanata & Epiphytic $^{\mathrm{e}}$ & $4.81(0.78)$ & $3.62(0.59)$ & $6.22(1.96)$ & $0.05(0.03)$ \\
\hline Hypnum cupressiforme var. filiforme & Epiphytic & $5.23(1.52)$ & $5.41(0.56)$ & $3.56(0.77)$ & $0.02(0.01)$ \\
\hline Hypnum cupressiforme & Epiphytic & $5.32(0.83)$ & $3.24(0.90)$ & $3.51(0.83)$ & $0.03(0.01)$ \\
\hline Anomodon viticulosus & Epiphytic & $3.64(1.09)$ & $4.72(0.81)$ & $2.98(1.03)$ & $0.07(0.02)$ \\
\hline Isothecium alopecuroides & Epiphytic & $4.43(0.39)$ & $5.42(1.99)$ & $6.10(4.21)$ & $0.08(0.06)$ \\
\hline Eurhynchium angustirete & Terrestrial $^{\mathrm{f}}$ & $6.29(0.23)$ & $4.81(1.30)$ & $4.23(1.18)$ & $0.03(0.01)$ \\
\hline Pleurozium schreberi & Terrestrial & $8.85(1.00)$ & $6.31(0.73)$ & $9.94(4.09)$ & $0.09(0.05)$ \\
\hline \multicolumn{6}{|l|}{ Non-used } \\
\hline Anomodon longifolius & Epiphytic & $2.29(0.33)$ & $2.58(0.51)$ & $1.64(1.06)$ & $0.03(0.02)$ \\
\hline Brachythecium salebrosum & Epixylic $^{\mathrm{g}}$ & $6.14(0.87)$ & $3.18(0.31)$ & $3.35(0.83)$ & $0.03(0.01)$ \\
\hline Homalia trichomanoides & Epiphytic & $3.49(0.13)$ & $2.35(0.40)$ & $2.38(0.95)$ & $0.03(0.02)$ \\
\hline Homalothecium sericeum & Epiphytic & $4.53(0.80)$ & $2.58(0.97)$ & $1.80(0.90)$ & $0.02(0.01)$ \\
\hline Neckera pennata & Epiphytic & $3.00(0.41)$ & $2.84(0.65)$ & $2.57(0.51)$ & $0.02(0.01)$ \\
\hline Plagiomnium cuspidatum & Terrestrial & $5.70(0.56)$ & $2.49(0.25)$ & $1.03(0.42)$ & $0.01(0.00)$ \\
\hline Plagiothecium nemorale & Terrestrial & $5.41(1.12)$ & $2.87(0.28)$ & $1.26(0.20)$ & $0.01(0.00)$ \\
\hline Sciuro-hypnum oedipodium & Terrestrial & $6.14(1.32)$ & $2.66(0.37)$ & $2.34(1.22)$ & $0.01(0.01)$ \\
\hline
\end{tabular}

Data are means and SDs. Moss bundles are shown in Electronic Supplementary Material, Fig. S2. Details of plucking and measuring procedures as given in the "Methods"

${ }^{a}$ Ratio of mass of fully water-saturated and dried fragments of moss wefts $(n=3)$

${ }^{\mathrm{b}}$ Length of the longest shoot $(n=5)$

${ }^{\mathrm{c}}$ Surface area of hand-plucked moss bundles $(n=5)$

${ }^{\mathrm{d}}$ Dry mass of hand-plucked moss bundles $(n=5)$

${ }^{\mathrm{e}}$ Bark of living trees

${ }^{\mathrm{f}}$ Ground layer

${ }^{\mathrm{g}}$ Decomposing logs

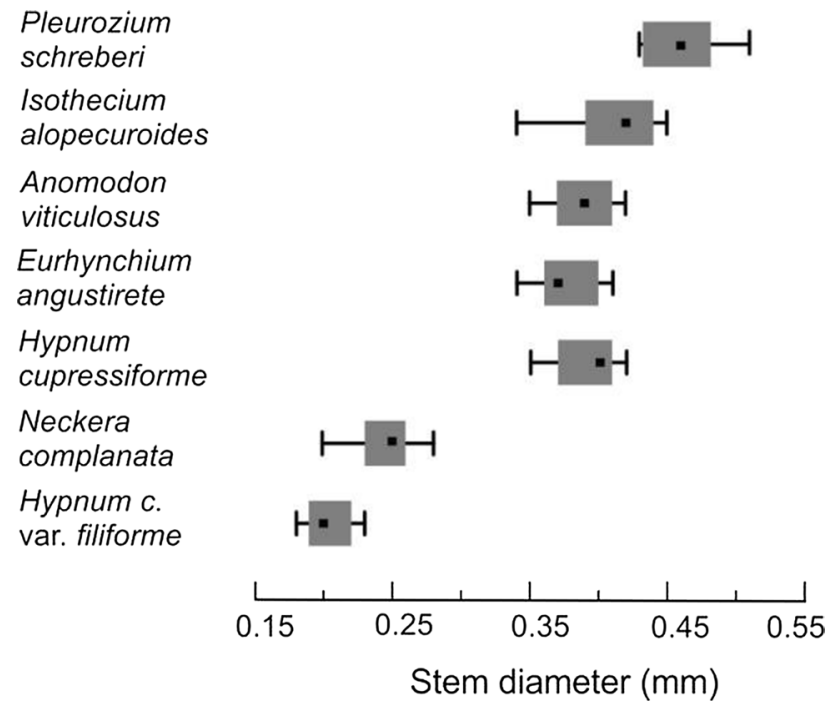

Fig. 4 Diameter of stems of moss species frequently used by the tits in the Białowieża NP. Squares indicate medians, boxes $25-75 \%$ quartiles, and whiskers ranges; $n=10$ in each case. Details of measurement procedures are given in the "Methods"
(400-500\% of their dry mass) was already adequate, and other features (see above) were of greater importance.

An additional, but so far hypothetical, reason for bryophyte selection could be their possible use as a defense against pathogens (Dubiec et al. 2013; D'Alba and Shawkey 2015). As extracts from several moss species show strong antimicrobial activity in the lab (Bukvički et al. 2012; Ertürk et al. 2015; Klavina et al. 2015), they could probably show some anti-pathogen activity in nature as well, and the birds might use those species exhibiting the strongest such properties.

In conclusion, we showed that the tits in the Białowieża NP appeared to be rather skilled bryologists. They seem to be able to recognize bryophyte species, and they collected them in a highly selective fashion. The birds concentrated on pleurocarpous mosses that grew as wefts, mostly on tree trunks; the used mosses were more profitable to collect, as they yielded larger bundles, with longer shoots, when plucked, than the non-used ones. The tit species differed in the sets of moss species that they collected. This variation was related to the mass of their broods; more robust mosses were used to provide support for the heavier broods 
of Great Tits, while the finest moss species were sufficient to form a cushion for the much lighter broods of Marsh Tits. It seems that these relationships should hold more generally, as suggested by the scant studies from other areas and species (Hřibek 1985; Hamao et al. 2016).

Acknowledgements The help of M. Czuchra, G. Hebda, M. Maziarz, G. Neubauer and P. Rowiński in the field data collection, as well as the kind cooperation of the Białowieża NP administration, is highly appreciated. B. Jaroszewicz kindly allowed us to use facilities of the Bialowieza Geobotanical Station University of Warsaw. We are grateful to A. Wiktoruk and I. Smerczyński (University of Warsaw) for assistance in the lab, to M. Reda, E. Młodzińska-Michta and M. Kossowska (Wrocław University) for making their lab equipment available to us, and to K. Wierzcholska for assistance in carrying out some of the measurements. We also thank R. K. Broughton and S. J. Reynolds for comments and linguistic help with the manuscript. The study was mostly funded by an internal grant from the Faculty of Biological Sciences, Wrocław University. S. W.'s fieldwork in 2016 was funded by the Polish-Norwegian Research Programme operated by the National Centre for Research and Development under the Norwegian Financial Mechanism 2009-2014 in the framework of project KlimaVeg, contract no. Pol-Nor/196829/87/2013.

Open Access This article is distributed under the terms of the Creative Commons Attribution 4.0 International License (http://creativeco mmons.org/licenses/by/4.0/), which permits unrestricted use, distribution, and reproduction in any medium, provided you give appropriate credit to the original author(s) and the source, provide a link to the Creative Commons license, and indicate if changes were made.

\section{References}

Ando H (1992) Studies on the genus Hypnum Hedw. (VIII). Hikobia $11: 111-123$

Autodesk (2018) AutoCad (computer-aided design and drafting software application), version 22.0. http://www.autodesk.com. Accessed July 2017

Barkman JJ (1958) Phytosociology and ecology of cryptogamic epiphytes. Assen, Van Gorcum

Bobiec A (2002) Living stands and dead wood in the Białowieża Forest: suggestions for restoration management. For Ecol Manage 165:121-136

Breil DA, Moyle SM (1976) Bryophytes used in construction of bird nests. Bryologist 79:95-98

Briggs KB, Deeming DCh (2016) Use of materials in nest construction by Pied Flycatchers Ficedula hypoleuca reflects localized habitat and geographical location. Bird Study 63:516-524

Bukvički D, Veljič M, Soković M, Grujić S, Marin PD (2012) Antimicrobial activity of methanol extracts of Abietinella abietina, Neckera crispa, Plathypnidium riparoides, Cratoneuron filicinum and Campylium protensum mosses. Arch Biol Sci Belgrade 64:911-916

Cholewa M (2015) Timing of breeding and nestling diet of the Great Tit Parus major in relation to food supply in primeval forest Białowieża National Park. Dissertation, Wrocław University

D’Alba L, Shawkey MD (2015) Mechanisms of antimicrobial defense in avian eggs. J Ornithol 156(Suppl 1):S399-S408

Deeming DC, Mainwaring M (2015) The functional properties of nests. In: Deeming DC, Reynolds SJ (eds) Nests, eggs, and incubation: new ideas about avian reproduction. Oxford University Press, Oxford
Dubiec A, Góźdź I, Mazgajski TD (2013) Green plant material in avian nests. Avian Biol Res 6:133-146

Ertürk Ö, Sahin H, Ertürk EY, Hotaman HE, Koz B, Özdemir Ö (2015) The antimicrobial and antioxidant activities of extracts obtained from some moss species in Turkey. Herba Polon 61(4):5265

Faliński JB, Mułenko W (1995) Cryptogamous plants in the forest communities of Białowieża National Park. General problems and taxonomic groups analysis (Project CRYPTO). Phytocoenosis 7. Arch Geobot 4:1-176

Glime JM (2015) Water relations: conducting structures. In: Glime JM (ed) Bryophyte ecology, vol 1. Physiological Ecology. Ebook. Chapts 7-1.Sponsored by Michigan Technological University and the International Association of Bryologists. Last updated 19 April 2015, http://www.bryoecol.mtu.edu

Glime JM (2017). Birds and bryophytes intersect. In: Glime JM (ed) Bryophyte ecology, vol 2. Bryological interaction. EBook. Chaps 16-1. Sponsored by Michigan Technological University and the International Association of Bryologists. Last updated 30 July 2017, http://digitalcommons.mtu.edu/bryophyte-ecology2/

Glutz von Blotzheim UN, Bauer K (1993) Handbuch der Vögel Mitteleuropas, vol 13. Akademische, Wiesbaden

Hamao S, Higuchi M, Jinbo U, Maeto K, Furuki K (2016) Interaction among birds, mosses and insects in birds nests. Jpn J Ornithol 65:37-42

Hansell M (2000) Bird nests and construction behaviour. Cambridge University Press, Cambridge

Hebda G, Wesołowski T (2012) Low flea loads in birds' nests in tree holes. Ornis Fenn 89:139144

Hrribek M (1985) The use species of moss (Bryophyta sp.) in the building of nests the Great Tits (Parus major L., 1758) and Blue Tit (Parus caeruleus L., 1758). Zprávy Moravského Ornitologického Sdruženi 43:39-45 (in Czech, English summary)

Klavina B, Springe G, Nikolajeva V, Martsinkevich I, Nakurte I, Dzabijeva D, Steinberga I (2015) Chemical composition analysis, antimicrobial activity and cytotoxicity screening of moss extracts (moss phytochemistry). Molecules 20:17221-17243

Mägdefrau K (1982) Life-forms of bryophytes. In: Smith AJE (ed) Bryophyte ecology. Chapman and Hall, London, pp 45-58

Maziarz M, Wesołowski T (2013) Microclimate of tree cavities used by Great Tits (Parus major) in a primeval forest. Avian Biol Res 6:47-56

Maziarz M, Wesołowski T (2014) Does darkness limit the use of tree cavities for nesting by birds? J Ornithol 155:793-799

Maziarz M, Wesołowski T, Hebda G, Cholewa M (2015) Natural nest-sites of Great Tits (Parus major) in a primeval temperate forest (Białowieża National Park, Poland). 2015. J Ornithol 156:613-623

Maziarz M, Wesołowski T, Hebda G, Cholewa M, Broughton RK (2016) Breeding success of Great Tits Parus major in relation to attributes of natural nest-cavities in a primeval forest. J Ornithol 157:343-354

Maziarz M, Broughton RK, Wesołowski T (2017) Microclimate in tree cavities and nest-boxes: implications for hole-nesting birds. For Ecol Manage 389:306-313

Meusel H (1935) Wuchsformen und Wuchstypen der europäischen Laubmoose. Nova Acta Leopoldina Neue. Folge 3(12):124-277

Niechoda T, Korbel J (2011) Puszczańskie olbrzymy. Towarzystwo Ochrony Krajobrazu, Białowieża (In Polish)

Ochyra R, Żarnowiec J, Bednarek-Ochyra H (2003) Census catalogue of Polish mosses. Polish Academy of Sciences, Institute of Botany, Kraków

Oksanen J, Blanchet FG, Kindt R, Legendre P, Michin PR, O'Hara RB, Simpson GL, Solymos P, Henry M, Stevens H, Wagner H (2016) vegan 2.3.3. Community ecology package. URL http://CRAN.Rproject.org/package=vegan. Accessed April 2017 
R Core Team (2015) R: a language and environment for statistical computing. R Foundation for Statistical Computing, Vienna. https ://www.R-project.org/. Accessed Apr 2017

Richardson DHS (1981) The biology of mosses. Wiley, New York

Slagsvold T (1989) Experiments on clutch size and nest size in passerine birds. Oecologia 80:297-302

StatSoft (2014) STATISTICA (data analysis software system), version 12. http://www.statsoft.com. Accessed June 2017

Szweykowski J (2006) An annotated checklist of Polish liverworts and hornworts. Polish Academy of Sciences, Institute of Botany, Kraków

Tomiałojć L, Wesołowski T (1990) Bird communities of the primaeval temperate forest of Białowieża, Poland. In: Keast A (ed) Biogeography and ecology of forest bird communities. SPB, the Hague, pp 141-165

Tomiałojć L, Wesołowski T (2004) Diversity of the Białowieża forest avifauna in space and time. J Ornithol 145:81-92

Wesołowski T (1996) Natural nest sites of Marsh Tits Parus palustris in a primaeval forest (Białowieża National Park, Poland). Die Vogelwarte 38:235-249

Wesołowski T (2001) Ground checks—an efficient and reliable method to monitor holes' fate. Ornis Fenn 78:193-197

Wesołowski T (2002) Antipredator adaptations in nesting Marsh Tits Parus palustris - the role of nest site security. Ibis 144:593-601

Wesołowski T (2003) Clutch size and breeding performance of Marsh Tits Parus palustris in relation to hole size in a primeval forest. Acta Ornithol. 38:65-72

Wesołowski T (2007a) Lessons from long-term hole-nester studies in a primeval temperate forest. J Ornithol 148(Suppl. 2):S395-S405. https://doi.org/10.1007/s10336-007-0198-1

Wesołowski T (2007b) Primeval conditions-what can we learn from them? Ibis 149(suppl. 2):s64-s77. https://doi.org/10.1111/j.1474919x.2007.00721.x
Wesołowski T (2013) Timing and stages of nest building by Marsh Tits Poecile palustris in a primaeval forest. Avian Biol Res 6:31-38

Wesołowski T (2015) Dispersal in an extensive continuous forest habitat: Marsh Tit Poecile palustris in the Białowieża National Park. J Ornithol 156:349-361

Wesołowski T, Martin K (2018) Tree holes and hole nesting birds in European and North American forests. In: Mikusiński G, Roberge J-M, Fuller RJ (eds) Ecology and conservation of European forest birds. Cambridge University Press, Cambridge, pp 79-134

Wesołowski T, Mitrus C, Czeszczewik D, Rowiński P (2010) Breeding bird dynamics in a primeval temperate forest over 35 years: variation and stability in a changing world. Acta Ornithol 45:209-232

Wesołowski T, Maziarz M (2012) Dark tree cavities-a challenge for hole nesting birds? J Avian Biol 43:454-460

Wesołowski T, Rowiński P (2012) The breeding performance of Blue Tits Cyanistes caeruleus in relation to the attributes of natural holes in a primeval forest. Bird Study 59:437-448

Wesołowski T, Rowiński P (2014) Do Blue Tits Cyanistes caeruleus synchronise reproduction with caterpillar peaks in a primeval forest? Bird Study 61:235-245

Wesołowski T, Czeszczewik D, Rowiński P, Walankiewicz W (2002) Nest soaking in natural holes-a serious cause of breeding failure? Ornis Fenn 79:132-138

Wesołowski T, Czeszczewik D, Hebda G, Maziarz M, Mitrus C, Rowiński P (2015) 40 years of breeding bird community dynamics in a primeval temperate forest (Białowieża National Park, Poland). Acta Ornithol 50:95-120

Wiśniewski T (1930) Les associations des Muscinees (Bryophyta) epiphytes de la Pologne, en particulier celles de la foret vierge de Białowieża. Bull Int Acad Pol Sci Lett Crac Ser B, 1 s: 293-342

Żarnowiec J, Klama H, Mułenko W (1996) The differentiation of forest communities and distribution of cryptogamous plants. Phytocoen Arch Geobot 6:163-172 